\title{
International Acquisitions: Spains Actividades de Construcción y Servicios (ACS) Battle for Control of Germanys Hochtief (HT)
}

\author{
Howard Sutton ${ }^{1}$, Kirstin Bremser ${ }^{1} \&$ Joachim Paul $^{1}$ \\ ${ }^{1}$ Business School, Pforzheim University of Applied Science, Germany \\ Correspondence: Professor Dr. Howard Sutton, Business School, Pforzheim University of Applied Science, \\ Tiefenbronnerstrasse 65, 75175 Pforzheim, Germany. E-mail: howard.sutton@hs-pforzheim.de
}

Received: July 23, 2014

doi:10.5430/ijba.v5n5p14
Accepted: August 6, 2014

Online Published: August 23, 2014

URL: http://dx.doi.org/10.5430/ijba.v5n5p14

\begin{abstract}
In March 2007 ACS purchased a holding in Hochtief of $25.08 \%$, at this time ACS stated that this was purely a strategic holding and no further involvement was planned. However, in September 2010 ACS announced that it intended to bid for the remaining shares. This started an exhaustive hostile takeover battle in which both parties used all instruments available to achieve their goals. Most literature considering acquisitions address either the question of how to select the most appropriate target or how to integrate the target once acquired (Post Acquisition Integration). This paper considers the key phase between target selection and PAI; that of convincing the current owners to sell their holdings to the acquiring company. This often public battle for control is crucial for the success of the acquisition company's strategy. This paper documents the battle for Hochtief by ACS in detail. Firstly, the relevant industries in which the companies are active are described briefly. Secondly, the company's current positions, controlling structures and driving personalities are introduced. Finally, the development of both the acquisition and defence tactics used by combatants is described in detail, which eventually resulted in ACS gaining control of Hochtief in June 2011.
\end{abstract}

Keywords: battle for control, international acquisition process, acquisition and defence tactics

\section{Introduction}

Control of another company is achieved by acquiring all or the majority of its shares from the current owners, often termed the Mergers \& Acquisitions (M\&A) process. Most publications considering the M\&A process either address the question of how to select the most appropriate target or how to integrate the acquired unit into the current management system. The first group emphasise the strategic and financial aspects and the second group the business and organizational aspects of integration (post acquisition integration PAI). However, between these two phases is a key stage or phase which is critical for the success of the M\&A process; that of convincing the current owners to sell their holdings. This is especially relevant when the management of the target company do not support the offer made and decides to defend the bid. From this point on, the battle for control takes place in the public domain and this also must be managed effectively. There is, unfortunately, relatively little documentation in the literature which considers this stage in detail.

This paper illustrates what can happen in this critical stage by documenting Spain's ACS bid for the German company Hochtief. This should provide an insight into the practical difficulties of both gaining control of a selected target or of defending a bid.

In 2011 twelve "mega deals" (deals with a transaction value of at least $\$ 1 \mathrm{bn}$.) were performed. The third biggest deal in terms of M\&A value was the acquisition of the German construction company Hochtief (HT) by the Spanish construction and infrastructure company 'Actividades de Construcción y Servicios' (ACS) ("Construction M\&A activity rises globally in 2010," 2011).

This acquisition was classified as a 'hostile takeover', a seldom occurrence in Germany. The first was registered as recently as 1997, and was a national affair when Krupp-Hoesch acquired and merged with Thyssen creating the Krupp-Thyssen AG. The most known example in Germany was the hostile takeover bid of the British company Vodafone for the German Mannesmann AG, which took place at the end of 1999. As a consequence, the German takeover law was tightened in 2002 in an effort to protected German companies from further hostile takeover bids. 


\section{General Description of the Global Construction Industry}

The global construction industry is normally considered to consist of two main segments: the construction \& engineering (CG\&E) and the general building (homebuilding) industries. The construction \& engineering is often called civil engineering industry and consists of: bridges, roads, airports, tunnels etc., including commercial, industrial and institutional buildings (none residential construction). The general building or homebuilding segment consists of primarily residential buildings including both houses and apartments.

\subsection{Global Construction \& Engineering (CG\&E)}

The CG\&E industry has two types of supplier; the distributors of construction materials and components, and sub-contractors providing specialized services or "know how". In general, materials required by the industry are relatively simple to manufacture and although the number of manufacturers is highly consolidated, the materials are freely available and competition is based upon price. Typically there are many sub-contractors available to provide the skills necessary for projects, especially since the financial crisis of 2007 which lead to a reduction in the demand for construction works, which puts them in a relatively weak bargaining position (Market Line, 2012).

The clients for CG\&E projects are either public institutions, from a national to communal level, or large private organizations. This means that the number of potential clients is relatively small and the purchasing process is controlled by the client who invites tenders from construction companies in a standardised way. Thus the clients have a strong negotiating position. The financial crisis in 2007 affected the industry adversely; the finance available for new projects has decreased. However, a number of countries have decided to counteract the downturn by increasing domestic spending on construction, but the pressure on prices remains high. Once a tender has been won and the project started, then the client's ability to switch to another provider is severely limited as the time and effort involved are often unacceptable. This means that other factors such as project efficiency or long term maintenance can play significant roles in winning a contract.

At present the companies in the industry provide a combination of managerial and technical skills, both of which are not quickly or easily obtained. It can be assumed that possibility of substitution of this service in the near future is minimal.

The level of regulation is often high and complex which serves as a significant entry barrier, foreign companies can even be restricted in some markets. The reputation of a company often plays a significant role in winning tenders. One of the critical issues in the GC\&E industry is the size of the company itself, for large international projects only a small number of companies can satisfy both the financial and technical demands required, and they often form a consortium if the risk is high. For small projects local or regional companies with be able to meet the requirements easily. The potential of new entrants into the market for large projects is low, but for small projects relatively high. New entrants do not need large amounts of capital because they can sub-contract most of the activities required, but they usually have to begin with small contracts to establish themselves.

The global industry can be described as fragmented, it is composed of a small number of international companies (in 2010 Hochtief (Germany) rank 1, Bechtel Group USA, Vinci \& Bouyges S.A (F), Skanska(Sweden), ACS (Spain) rank 18) (Engineering News record, 2011), a medium number of national or regional companies and many small regional companies. This fragmentation leads to intense rivalry when tendering for a project. To avoid the intensity of competition some companies have diversified into related industries, such as building maintenance etc.

The forecast for the near future is an expected average growth rate from 2011-16 to be approximately 5.0\% CAGR (Market Line, 2012).

The Tables 1-3 provide some general information about the size and past growth of the industry.

Table 1. Global construction and engineering industry

\begin{tabular}{cccc}
\hline Year & $\begin{array}{c}\text { Value } \\
\text { (\$ billion) }\end{array}$ & $\begin{array}{c}\text { Value } \\
\text { (billion } \boldsymbol{\epsilon} \text { ) }\end{array}$ & $\begin{array}{c}\text { \%Growth on } \\
\text { previous year }\end{array}$ \\
\hline 2007 & $2,860.6$ & $2.056,2$ & - \\
2008 & $3,103.5$ & $2.230,8$ & 8.5 \\
2009 & $3,081.5$ & $2.215,0$ & $(0.7)$ \\
2010 & $3,004.6$ & $2,159,7$ & $(2.5)$ \\
2011 & $3,120.9$ & $2.243,3$ & 3,9 \\
\hline CAGR & & & 2.2 \\
$2007-11$ & & & \\
\hline
\end{tabular}

Size and growth of the industry

Source: (Market Line, 2012) 
Table 2. Global construction and engineering segmentation in 2011

Relative sizes of the categories

\begin{tabular}{lcc}
\hline \multicolumn{1}{c}{ Category } & Value 2011 (billion & $\%$ \\
& $\mathbf{\$}$ ) & \\
\hline Civil Engineering & $1.734,6$ & 55.6 \\
Non-Residential Building & $1.386,3$ & 44.4 \\
\hline
\end{tabular}

Source: (Market Line, 2012)

Table 3. Global construction and engineering geographical segmentation in 2011

\begin{tabular}{lcc}
\hline \multicolumn{1}{c}{ Region } & Value 2011 (billion & $\%$ \\
\hline Asia-Pacific & $\mathbf{\$ )}$ & \\
Americas & $1,385,5$ & 44.4 \\
Europe & 773,3 & 24.8 \\
Middle East \& Africa & 730,0 & 23.4 \\
\hline
\end{tabular}

Sizes of the regions

Source: (Market Line, 2012)

\subsection{General Building Industry (GB)}

The GB industry has four main types of suppliers; the suppliers of building materials, sub-contractors, the owners of land for building, as well as the providers of finance. The suppliers of building materials are numerous and local. Similarly, there is no shortage of sub-contractors as the skills required are not high; labour is plentiful in most areas. The owners of land have a relatively strong bargaining position as land is in many areas a scarce resource and demand is high. The providers of finance are normally private institutions who lend against specific conditions, such as resale value etc. Since the financial crisis of 2007 the availability of such finance has reduced considerably (Datamonitor, 2011)

The end consumers are generally private individuals and small companies, who are particularly price sensitive and cautious when making their final decision. There are many varieties of residential accommodation and there are also alternative areas to be considered, this coupled with the fact that there is little or no loyalty to developers results in a relatively strong bargaining position. Demand for such homes are particularly sensitive to macroeconomic factors such as: interest rates, wages, and the availability of finance.

It can be said that substitutes in the sense of a new form of product will not exist in the near future, but there are alternatives for different parts of a standard product, i.e. heating systems, energy systems etc. One form of substitute which does change is that of ownership, to buy or to rent, but this does not impact the developers significantly.

The intensity of competition can be described as high as there are many participants ranging from large international (Vinci (F), Bouygues (F), Kajima (Japan), ACS (Spain)) to local companies. There are no significant investments required, much of the equipment necessary can be hired and does not need to be purchased. The skills required are relatively low level and if any extra are needed they can simply be hired (sub-contracted). The costs of exiting the industry are low. Most countries appear to be undergoing a period of consolidation at the moment and a number of companies are beginning to diversify.

The major issue determining whether companies enter the market is the growth rate of the industry in the region. In 2011 high growth rates were evident in Asia-Pacific region and low rates in Europe and America. Government regulations, often used to promote local companies, still exist in a number of countries. Larger companies have an advantage in that they are able to purchase in bulk and attain lower cost positions.

The forecast for 2010-2015 is an average growth rate of 12.9\% CAGR, in the Asian-Pacific region of $12 \%$ CAGR and $8.7 \%$ in Europe (Datamonitor, 2011).

The Tables 4 and 5 provide some general information about the size and growth of the industry in the recent past. 
Table 4. Global homebuilding industry

\begin{tabular}{cccc}
\hline Year & Value (million \$ ) & Value (million $\mathbf{\epsilon})$ & \% Growth \\
\hline 2006 & $5,056.9$ & $3,808.2$ & - \\
2007 & $5,385.8$ & $4,055.9$ & 6,5 \\
2008 & $6,015,7$ & $4,530.3$ & 11.7 \\
2009 & $5,981.2$ & $4,504.3$ & $(0, .6)$ \\
2010 & $6,077.6$ & $4,576.9$ & 1.6 \\
& & & 4.7 \\
\hline CAGR 2006-10 & & & \\
\hline
\end{tabular}

Size and growth rate of the industry.

(Datamonitor, 2011)

Table 5. Global homebuilding industry geographical segmentation in 2010

\begin{tabular}{lc}
\hline \multicolumn{1}{c}{ Region } & \% Share by Value \\
\hline Asia-Pacific & 79.7 \\
Americas & 9.9 \\
Europe & 9.3 \\
Middle East \& Africa & 1.1 \\
\hline
\end{tabular}

Size of the regions.

(Datamonitor, 2011)

\section{Hochtief (HT) Company Profile}

Hochtief was founded in 1875 in Frankfurt am Main as Gebrüder Helfman (Helfman Brothers) by Philipp (a mason) and Balthasar (a metal worker) Helfmann. In 1896 the company was converted into a joint stock company "Aktiengesellschaft für Hoch- und Tiefbauten". During the Hyperinflation of the 1920's the majority of the shares were purchased by Rheinische-Westfalische Elektizitätswerk (RWE) and Allgemeine Elektizitäts Gesellschaft (AEG). In the Third Reich business flourished and Hochtief profited from public works such as motorways and industrial buildings. Similarly the company profited from the post second world war reconstruction works. In 2004 RWE sold its stake in Hochtief and at the end of $200480 \%$ of its shares were free floating.

Until the 1990s Hochtiefs primary business was the construction of projects both above and below ground level. Since 1990 Hochtief has become active in other parts of the typical value chain, i.e. planning, operating, maintaining and change of purpose activities. Currently a strategy of life cycle management is being pursued, which extends the services offered to recycling and disposal of buildings. Hochtief is now able to offer all services to its clients throughout a projects life cycle. A second strategic dimension is the geographic expansion of its markets. This began after the Second World War but a second phase started in 1999, when the construction boom after German reunification began to slow. In 1999 the Turner Corporation (USA) was acquired and in 2001 a majority shareholding (54\%) in The Leighton Group (Australia) was purchased. In 2006 a number of projects were acquired in Eastern Europe and in 2007 Flatiron (USA/Can) was acquired and a number of projects in the Middle East began. In March 2010 Hochtief announced that the strategy will include expanding their involvement in the offshore wind business and that the regions of India, Canada and the Middle East, especially Qatar, will be the main focus. An example of these strategic developments is the Elefsina-Patras-Tsakona toll road in Greece, it is a Public Private Partnership (PPP) project in which the company is designing, financing and building the 365-kilometer roadway (Datamonitor, 2010b).

Currently, Hochtief is organised in four corporate divisions: HT Americas, HT Asia Pacific, HT Europe and HT Concessions. In 2011 approximately 92\% of turnover was earned outside of Germany, which according to the Engineering News Record statistics makes HT the most International construction company (Engineering News record, 2011). HT Americas is dominated by Flatiron which is a leading company for complex infrastructure projects such as bridges and roads. E.E. Cruz, which was recently acquired, focuses on heavy construction projects in the New York metropolitan area, where extensive modernization projects are planned for the future (Datamonitor, 2010b). Approximately 53\% of total revenue is generated in HT Asia Pacific, where Leighton holds a leading position in Australia and is expanding its technical expertise in the mining, water and energy businesses and regional 
presence into other Asia countries, India and the Gulf States. HT Europe consists of the original construction business (including residential property development), HT Real Estate and HT Services (facility and energy management) and provides approximately $12 \%$ of total revenues. HT Concessions is a leading provider of infrastructure, also through Public Private Partnership (PPP) solutions, and accounted for approximately $0.5 \%$ of total revenues in 2010 (Hochtief AG, 2011a).

The Hochtief group is controlled from the headquarters in Essen, Germany by the executive board of five members who report to the supervisory board: Dr. H. Lütkestrakötter (Chairman), Dr. B. Lohr (CFO), Dr. P. Noe (responsible for Asia Pacific and Concessions), Dr. M. Rohr (responsible for Americas) and Dr. F. Stieler (responsible for Europe). The supervisory board consists of: D. Bremkamp (Chairman from 11.05.2010, management consultant), Á. G. Altozano (ACTIVIDADES DE CONSTRUCCIÓN Y SERVICIOS, S.A., Madrid), Manfred Wennemer (formerly Continental AG), M.F. Verdes (ACS group), T. Todenhöfer (Rober Bosch, Madrid), Professor Dr. W. Simson (EON AG), Professor Dr. Heinrich v. Pierer (Pierer Consulting), Dr. M. Kohlhaussen (Commerzbank AG) and eight further representatives of Hochtiefs employees (Hochtief AG, 2011a).

Dr. Herbert Lütkestrakötter was born in 1950 and studied mechanical engineering at the University in Aachen, graduating with a doctorate. He was employed by several construction companies before he joined Hochtief in 2006. Immediately before joining Hochtief he was director of operations at Phlipp Holzmann AG, where he was involved in a protracted but unsuccessful insolvency. In his spare time he is a keen marathon runner and in 2009 ran a marathon in 3 hours 32 minutes. He leads a modest lifestyle and is said not to be particularly motivated by money. Although he prefers to be called Mr. Lü this does not mean that he is a "soft touch", quite the contrary at times (Winand von Petersdorff, 2010).

The revenues of Hochtief have almost doubled since 2003 to reached 20.16 billion $€$ in 2010. Apart from the year 2009 revenues had experienced constant growth (refer to Table 6).

Table 6. General financial information for Hochtief

\begin{tabular}{lcccccc}
\hline & $\mathbf{2 0 0 5}$ & $\mathbf{2 0 0 6}$ & $\mathbf{2 0 0 7}$ & $\mathbf{2 0 0 8}$ & $\mathbf{2 0 0 9}$ & $\mathbf{2 0 1 0}$ \\
\hline Revenues (billion $€$ ) & 13.65 & 15.47 & 16.45 & 18.70 & 18.17 & 20.16 \\
EBIT (million $€$ ) & - & - & 501 & 497 & 597 & 757 \\
Consolidated net profit (mill $€$ ) & 68 & 89 & 141 & 157 & 192 & 288 \\
Share price $(€$ rounded) & 25 & 57 & 78 & 68 & 35 & 57 \\
(beginning of May) & & & & & & 2,048 \\
Financial liabilities (long term billion $€$ ) & - & - & - & - & & 2,577 \\
Number of employees & & & & & & 70,657 \\
\hline
\end{tabular}

Source: (Statista Inc.), (Deutsche Borse Group - Xetra) and (Hochtief AG, 2011a)

Dividends have also tripled between 2003 and 2010 from $0,5 €$ to $1,5 €$ per share. At this time a number of commentators suggested that Hochtief was using Germanys accounting standards to increase provisions generously and reduce the stated profits, thus making Hochtief appear undervalued.

Preceeding the offer from ACS (December 2009) the shareholder structure of Hochtief was as follows: free float 65.08\%, Actividades de Constuccion Y Servicios SA. (ACS) 29.98\%, and Treasury Stock (4.94\%) (Hochtief AG, 2010a).

\section{Actividades de Construccion y Servicios (ACS)}

Actividas de Construccion Y Servicios was established in 1997 when the company OCP Construcciones SA merged with the construction companies Auxini and Gines Navarro SA. Previous to this, OCP was the result of a merger in 1992 between Construcciones Padros (CP), a major Spanish construction company which was established in 1988, and three other Spanish companies; OCISA Construccion, Cobra and Semi who were both industrial service companies. In 2000, ACS acquired a stake in the telecommunication company Xfera Moviles. ACSs main competitor, Groupo Dragados, was acquired in 2003 and also a stake (25.8\%) in Albertis, a leading infrastructure management company, was acquired. In 2005, and 2006 ACS established its base for its energy business by obtaining stakes in both Union Fenosa and Iberdrola. In 2007, ACS purchased a significant stake in Hochtief, marking the beginning of reducing its reliance upon the Spanish market. In 2009, the Polish company POL-Aqua was acquired, followed by the acquisition of the American companies John. P. Picone Inc. and Pulice Construction Inc. in 2010. The stake in Iberdrola was also increased in the same year (Actividades de Construccion y Servicios (ACS), 2011a). 
ACS focussed initially on the construction business which has been successively extended to include: industrial services, power transmission lines and energy. Regionally, the company has been focussed in Spain, but has recently begun to internationalise its operations, especially in Europe, Mexico and North America, as evidenced by the contribution of international to total sales; only 15\% in 2005 it increased to $32 \%$ in 2010.

As a result of its M\&A activities, ACS consisted of 587 fully consolidated companies, 90 associated companies and 44 joint ventures. ACS is organized into four different business areas: construction, concessions, environment, and industrial services and energy. The construction business was responsible for approximately $36 \%$ of total revenues in 2010, 16\% lower than 2008 due to the crisis in Spain, and is divided into the: civil works, residential and non-residential business segments. Civil works includes: motorways, railways and port installations; residential includes both private and social housing; non-residential includes administrative buildings, hospitals, schools etc. The industrial service business consists of industry support services and energy projects and accounted for approximately $47 \%$ of total revenues in 2010. The industrial services includes: network maintenance (gas and electricity), special installations (transmission lines) and control systems (for example signal or climate systems). Energy projects are typically turnkey projects for oil and gas, although renewable energy projects, for example solar thermal power plants are becoming increasingly important. The environmental services business, which was responsible for approximately $17 \%$ of total revenues in 2010 , consists of environmental services, the provision of waste management and energy recovery (co-generation) services, and integrated services, i.e. airport services, catering for hospitals and facility management. Facility management is becoming more interesting because of the increasing willingness of companies to "outsource" activities. The concessions business contributed only $0,8 \%$ to total revenues in 2010, although this corresponds to an increase of 50\% compared to the previous year. This business is specialized in various forms of public private partnerships (PPP) and is performed predominantly by Iridium Concesiones de Infrastructuras SA (Datamonitor, 2010a).

ACS has its headquarters in Madrid, Spain. The chairman and CEO is Mr. Florentino Pérez Rodríguez, Mr. Antonio García Ferrer (executive vice chairman), Mr. Pablo Vallbona Vadell (vice chairman) The remaining members of the board are: Mr. José María Loizaga Viguri, Mr. José María Aguirre González, Mr. Agustín Batuecas Torrego, Mr. Álvaro Cuervo García, Mr. Manuel Delgado Solís, Mr. Javier Echenique Landiríbar, Ms. Sabina Fluxá Thienemann, Mr. Joan-David Grimà i Terré, Mr. Pedro López Jiménez, Mr. Juan March de la Lastra, Mr. Santos Martínez-Conde Gutiérrez-Barquín, Mr. Javier Monzón de Cáceres, Mr. Miquel Roca i Junyent, Mr. Julio Sacristán Fidalgo, Mr. Francisco Servando Verdú Pons and Mr. José Luis del Valle Pérez (Secretary of the Board of Directors). All members are also representatives of the boards of affiliated companies; none are representatives of the employees (Actividades de Construccion y Servicios (ACS), 2011a).

Mr. Florentino Pérez Rodríguez was born in Madrid in 1947 and after finishing his degree in engineering worked as a politician in the Spanish government. In 1983, he joined Construcciones Padros becoming their top executive in 1984. Since 1993, he has been effectively the Chairman and CEO of the ACS Group, first as the chairman of OCP Construcciones S.A. and then ACS. He also owns approximately 13\% of ACS shares and has been responsible for the development of ACS to date. He has well developed political and social networks, in particular with the major Spanish banks which has been beneficial to the development of ACS by acquisition. It has often been suggested that he leads ACS similarly to the way he leads his football club - he is also President of Real Madrid. He is noted for purchasing players and selling them for a higher price at a later date. This business model is also evident at ACS, which purchased a stake in Union Fenosa and two years later sold it for a profit of 2 billion Euros (Grüttner, 2011). $\mathrm{He}$ is also noted for his persistence. In 2008, ACS took 5\% share in Iberdrola, since then their CEO Sanchez Galan has been trying to prevent ACS influencing Iberdrola and at present legal action is being undertaken to force ACS representation on the supervisory board.

Table 7. General financial information for ACS

\begin{tabular}{lcccccc}
\hline & $\mathbf{2 0 0 5}$ & $\mathbf{2 0 0 6}$ & $\mathbf{2 0 0 7}$ & $\mathbf{2 0 0 8}$ & $\mathbf{2 0 0 9}$ & $\mathbf{2 0 1 0}$ \\
\hline Revenues (billion $€$ ) & 12.11 & 14.07 & 15.34 & 15.28 & 15.87 & 14.33 \\
EBIT (million $€$ ) & - & 942 & 1,056 & 1,042 & 1,074 & 1,099 \\
Consolidated net profit (mill $€$ ) & - & 1,250 & 1,551 & 1,805 & 1,946 & 1,313 \\
Share price $(€$ average of year) & - & 33.53 & 43.08 & 32.66 & 34.46 & 33.58 \\
Net Debt (billion $€$ ) & - & 8.75 & 7.94 & 9.36 & 9.09 & 8,00 \\
Number of employees & & & & & & 138,542 \\
\hline
\end{tabular}

Source: (Statista Inc.) and (Actividades de Construccion y Servicios S.S.) 
ACSs revenues increased steadily until 2008 when the financial crisis weakened the construction industry, especially in Spain. A significant part of the differences between the EBIT and consolidated net profit can be explained by sales of assets within the group. It is interesting to note the size of the net debt, a consequence of growth financed by debt.

The ownership structure of ACS is as follows: Corporación Financiera Alba S.A. 23.31\%, Corporación Financiera Alcor S.A. 13.86\%, Inversiones Vesán S.A. 12.52\%, Southeastern Asset Management Inc 6.47\%, Fluxá Rosselló Miguel 5.64\%, and the remainder (approx. 39\%) being free float. Corporación Financiera Alcor S.A. is a company wholly owned by Mr. Perez.

\section{Development of the Take-Over Process - Battle Begins}

On $20^{\text {th }}$ March 2007 ACS announced that it has obtained 25,08\% of Hochtief's shares from the German investor Custodia for a price of $72 €$ per share and a total cost of $1.264 €$ billion. Custodia had purchased the shares in 2005 and 2006 for approximately $40 €$ per share and is reported to have made a profit of $500 €$ million. ACS commented that this purchase would "increase and accelerate its international expansion in the United States, Central Europe and the Asia Pacific region" and that the group has "no intention to increase this stake" (ACS Group, 2007). Hochtief had hoped that Custodia block of shares would protect it from an acquisition and speculation about a take-over and possible break-up of Hochtief began ("Neuer Großaktionär aus Spanien," 2007).

On $25^{\text {th }}$ February 2008 Hochtief reported that ACS had increased its holding of Hochtief shares to around $30 \%$. ACS commented that this increase was only a theoretical increase which was achieved through some derivatives ("ACS erhöht Anteil an Hochtief," 2008).

Hochtiefs board announced on the $16^{\text {th }}$ September 2010 that it had received a statement from ACS confirming its intention to bid for the remaining shares, and that the board would consider the situation before giving a recommendation to the shareholders (Hochtief AG, 2010b). The bid was made when Dr. Lütkestratkötter was on holiday in an Austrian mountain lodge, this ACS knew through their representatives on the supervisory board which had met just before he went on holiday (Winand von Petersdorff, 2010).

Subsequently the supervisory board met on the $4^{\text {th }}$ October 2010, excluding the two ACS representatives, and demonstrated its support for the Hochtief board in ensuring the interests of Hochtief AG, its shareholders and employees are met. Representatives of the works council, fearing mass dismissals and sale of parts of the company, announced that they "will fight for their jobs" and that protests will be made not only within the company but also at the German Ministry for Economics and Technology (Minister R. Brüderle) and the Ministry for Labour and Social Affairs (Minister U. von der Leyen) ("Hochtief: Aufsichtsrat steht zur Abwehrfront," 2010). Despite the promised defence of the take-over, ACS repeated that they intend to develop a co-operative relationship and that a controlling agreement (Beherrschungsvertrag) is not planned.

In October Hochtief recognised that there was a potential loophole in the German takeover law (Wertpapiererwerbsund Übernahmegesetz WpÜG) compared to most other European countries and that this was to ACSs advantage. The loophole allowed what is termed as "creeping in". Normally, when a company has control of over $30 \%$, then it is obliged to make an offer for all other shares at a price which is the average market price over the past three months. With creeping in, a voluntary offer is made when the company has control of just under $30 \%$ of the shares and it can still buy from the market. The offer price is kept low so that only a few offers are accepted, but the control hurdle of $30 \%$ is breached. This means that when the offer expires the company can continue to buy shares freely from the market as usual, without a price premium, and under no obligation to present a mandatory offer for the remaining shares.

Hochtief's idea was to promote changing the law and forcing ACS to present a compulsory offer for the remaining shares when the $30 \%$ hurdle had been breached, thus stopping ACSs takeover bid by making it more expensive (Baums, 2010). To do this representation was made with a number of political leaders: Sigmar Gabriel (leader of the centre-left - SPD), Hannelore Kraft (SPD Premier of Nordrhein Westpfalen) as well as Reiner Bruederle (liberal FDP party) and the Prime Minister Angela Merkel (centre-right CDU party). To change a law of this type a majority of two thirds is necessary in Parliament and although Mr. Gabriel and Mrs. Kraft were sympathetic for a change their party did not have a majority.

The crown jewel in Hochtiefs portfolio was its $54.4 \%$ holding in The Leighton Group, a holding that has worked successfully for many years. Hochtief submitted a complaint to the Australian Securities and Investment Commission (ASIC) on $5^{\text {th }}$ Oktober 2010, stating that ACS should be obliged to make an offer to all Leighton's shareholders, thus making the offer significantly more expensive as Leighton is estimated to be worth approximately 8 billion Euros, twice the value of Hochtief. Unfortunately, the ASIC did not agree with Hochtief stating that a 
takeover offer for Leighton is not necessary, and passed the issue to the Australian "Takeover Panel" for further consideration ("Hochtief kämpft weiter um australische Giftpille," 2010). Simultaneously, Leighton applied to the ASIC as it saw "unacceptable circumstances" for the Leighton shareholders should the ACS bid be successful because they feared that Leighton would lose its independence. Currently, it has its own management and supervisory boards which guarantee its independence and these are not guaranteed if ACS takes over Hochtief ("Hochtief: Aufsichtsrat steht zur Abwehrfront," 2010). In its application Leighton proposes that ACS either declares that the current independence will be guaranteed or that an offer be made to all Leighton shareholders. This submission to ASIC was also passed to the Australian Takeover Panel for consideration.

On the $19^{\text {th }}$ October 2010, the German chancellor stated that she could see nothing illegal with ACSs behaviour and does not need to amend the current takeover law (WpÜG) to protect Hochtief from a takeover. The Economics Minister Rainer Brüderle also stated that he saw no need to change the current law ("Baukonzern Hochtief bleibt auf sich gestellt," 2010). On the $25^{\text {th }}$ October the socialist party did pass a resolution to change the law, although they had no power to.

The Prime Minister brokered a meeting between Hochtiefs CEO Mr. Lütkestratkötter and the Qatar Minister for Economics on $25^{\text {th }}$ October 2010. Qatar possesses a Sovereign Fund which has already invested in a number of large German companies and could provide support for Hochtief ("Hochtief-Abwehr gegen ACS nimmt Formen an," 2010). Hochtief has a number of business interests in Qatar, and the relationship could be developed beneficially for both parties.

Undeterred by the recent refusals to change the takeover law, Hochtief's employees supported by the works council marched to the Economics Ministry in Berlin where they handed a petition to the Minister Rainer Brüderle. Unfortunately, the works council reported that the reception from the Ministers representatives was "lukewarm". The employees then marched to the Parliament where they were received by Sigmar Gabriel, the SPD leader who confirmed that the SPD had applied for a change to the takeover law (WpÜG) (Wenten, 2010).

The Australian Takeover Panel rejected the appeals from both The Leighton Group and its major shareholder Hochtief on the $8^{\text {th }}$ of November (Fickling, 2010).

An extraordinary annual general meeting (AGM) for ACS was held on the 18 November 2010 and a conditional capital increase of 157 millon shares, nominal value $0.5 €$, was agreed. The proceeds of the capital increase are to be used for the acquisition of shares in both Hochtief and the Spanish energy company Iberdrola ("Baukonzern ACS kann Hochtief jetzt überrennen," 2010), which is also being vehemently contested by its President Jose Ignacio Sanchez Galan. In addition, ACS announced on $25^{\text {th }}$ November 2010 that it would sell its renewable energy division in Spain ("Hochtief-Angreifer beschafft sich frisches Geld," 2010).

On the $2^{\text {nd }}$ December 2010 ACS presented its official offer to Hochtief's shareholders. The offer had been submitted to Bafin (Federal Financial Supervisory Authority) on $12^{\text {th }}$ November and it was approved on $29^{\text {th }}$ of November. The offer, which was valid until $29^{\text {th }}$ December, was eight ACS shares for five Hochtief shares. This values each Hochtief share at $57.52 €$ compared to the actual market value of approximately $63 €$ ("Hochtief-Aktionäre verschmähen ACS-Offerte," 2010). It is hardly surprising that no offer for Hochtief shares had been accepted. This voluntary offer together with the current German takeover law allows ACS to buy further shares on the free market once the offer period has lapsed. This possibility could have been closed by a change in the German law to make it consistent with the majority of European countries.

On $6^{\text {th }}$ December 2010 Hochtief announced that the board had used part of the capital increase approved on $11^{\text {th }}$ May 2010 to secure a new major shareholder, Qatar Holding LLC. Almost 7 million (6.999.999) additional shares were issued at a price of 57.114€ per share. The shares were paid for in cash which provided Hochtief with an extra 400 Million $€$ and diluted ACSs Holding in Hochtief from 29.98\% to circa 27\% ("Qatar Holding wird neue Großaktionär von Hochtief," 2010). This action prompted one of the major shareholders, Southeastern Asset Management Incorporated, to complain in writing and demanded that the decision be reversed and that those members of the management and supervisory board who supported this action resign. Mr. Lütkestratkötter emphasised that this was part of a long term strategy that is beneficial to both the company and its shareholders.

In an interview on $12^{\text {th }}$ December, Mr. Lütkestratkötter stated that Hochtief would play a significant role in building a number of venues for the Football World Cup in 2022 in Qatar. He also stated that he is a person open to any dialogue and that the new major shareholder Qatar Holding LLC was prepared to act as a constructive mediator in any dialogue between Hochtief and ACS. He mentioned that if it appeared that the relationship between Qatar and 
Hochtief was meant to hinder ACSs ambitions, then that is a side effect that he will have to accept ("Hochtief bietet ACS Gespräche an," 2010).

ACS improved its offer to Hochtief shareholders on $16^{\text {th }}$ December 2010 from eight ACS shares for five Hochtief shares to nine ACS shares for five. This new offer valued the Hoctief shares at around $63 €$ per share. Although this was a significant improvement upon the original offer, the market value on the afternoon of the same day was $64.60 €$ ("Aufgestockte ACS-Offerte nicht angemessen," 2010).

On $29^{\text {th }}$ of December Hochtiefs CFO Burkhard Lohr announced that "it had adapted all important loan contracts to the current situation" ("ACS-Angriff auf Hochtief Ringfencing-Agreement soll Bonität sichern," 2010). This involved a "Ringfencing Agreement" in which the management is obliged not to sign any contracts which would reduce Hochtiefs credit worthiness. If the management breached this obligation, then the banks have the right to terminate contracts. Mr. Lohr also mentioned that the takeover bid had already increased the cost of credit for Hochtief and negotiating the ringfence agreement had also involved re-negotiating the current contracts which resulted in higher finance costs.

At the same time, an internal conflict appeared between the representatives of Hochtiefs employees. The works council (Chairman, Siegfried Müller) accused the union IG Bau (head of the union, Klaus Wiesehügel) of reaching a clandestine agreement with ACS which benefits IG Bau at the cost of the employees. IG Bau stated it had reached an agreement which would prevent ACS breaking up Hochtief and also the dismissal of 11.000 employees. Neither the works council nor the board had participated in these negotiations and Siegfried Müller commented that this was not the expected form of co-operation between the employee's representatives and demanded the resignation of both the IG Bau representatives on the supervisory board (SPIEGEL ONLINE, 2010).

Just before the end of deadline for the first offer on $29^{\text {th }}$ December ACS announced that they had obtained another 90.000 shares which in total corresponds to $29.4 \%$ of the voting rights, and were confident that they would achieve the $30 \%$ hurdle, especially as the deadline for the second offer expires on $18^{\text {th }}$ of January. Reaching $30 \%$ was important because it would enable ACS to buy shares on the free market and not have to make an obligatory offer to the remaining shareholders. ACS reiterated that it is in no hurry to obtain more than $50 \%$ of Hochtiefs shares.

On $4^{\text {th }}$ January 2011 Hochtief approached the Federal Financial Supervisory Authority (BaFin) and asked that the ACSs takeover offer be declared null and void. The reason for this was that ACS and the US investor Southerastern Asset Management (SEAM) had secretly collaborated with one another, so called "acting in concert", and Hochtief presented the evidence for this. Firstly, shortly before ACS announced their offer SEAM increased their holding to over 3.6 million shares. Secondly, at the beginning of December SEAM commented they estimated the true value of the shares to be circa $95 €$, nonetheless they suggested that they would be prepared to sell half of their holding - at a significantly lower price. Thirdly, after the second offer was announced on the $15^{\text {th }}$ of December, ACS stated that they were confident that would obtain over $30 \%$ of the shares; and a day later SEAM announced that they would accept the offer for half of their shares. Bafin did not comment upon the accusation (Weishaupt, 2011a). If this were deemed true by BaFin, ACS would have to make an obligatory offer to all the shareholders, which would have raised the cost of gaining control of Hochtief.

ACS announced on the $20^{\text {th }}$ of January that it had gained acceptance for 900.000 shares which corresponded to $31,6 \%$ of Hochtiefs shares. Hochtiefs reaction was to acknowledge the current situation and wait until the $3^{\text {rd }}$ February; the date shareholders officially have to reconsider their decision to sell (Reimann, 2010). ACS was now able to purchase shares from the free market without having to make an expensive obligatory offer to the remaining shareholders.

The Federal Financial Supervisory Authority (BaFin) stated on the $25^{\text {th }}$ January 2011 that "it had not found any indications of oral or written agreements, or any other form of concerted action regarding the joint acquisition of shares of Hochtief" and that its amended offer document of $15^{\text {th }}$ December 2010 was therefore admissible (BaFin, 2011).

Peter Noe, the board member responsible for concessions and the Asia-Pacific business announced on the $11^{\text {th }}$ March 2011 that he would be taking advantage of the "change of control" clause in his contract and would leave the company on $10^{\text {th }}$ September 2011 ("Peter Noe geht: Erster Hochtief-Manager flieht vor ACS," 2011). It was suggested that this clause would enable him to leave the company with two and a half years salary.

On the 22nd of March 2011, Hochtief announced record results for the year 2010. Turnover had improved by $11 \%$ to 20.16 billion $€$, new orders had increased by $31.8 \%$ to 29.63 billion $€$, the EBT had improved by $26.8 \%$ to 756.6 million $€$, and the net profit increased by $50,3 \%$ to 288 million $€$. As a result of this the dividend was increased by 50 
cents to $2 €$ per share (Schulz, 2011). For the next year the net profits were forecast to be significantly higher at around 600 million€.

Hochtiefs supervisory board met on the 22th March 2011 and prepared a list of candidates for the supervisory board to be elected in the Annual General Meeting (AGM) on the 12 May 2011. This was done without considering the wishes of ACS. The list consisted of: Manfred Wennemer (supposedly a supporter of ACS), Heinrich von Pierrer, Hans-Peter Keitel (Chairman of Employers Association), Detlev Bremkramp (current Chairman of the supervisory board), Wilhelm Simson (former EON), a representative from Qatar and the two current representatives from ACS ("Streit zwischen Hochtief-Aufsichtsrat und ACS eskaliert," 2011). ACS commented that they were disappointed that their wishes were not considered in the list, especially when their current shareholding of $41 \%$ permitted them to propose 4 of the 8 seats available.

On $10^{\text {th }}$ April, Hochtief announded that the Chairman Dr. Herbert Lütkestratkötter would be leaving the company on $12^{\text {th }}$ May (Hochtief AG, 2011b) and one week later it was announced that the CFO Burkhardt Lohr would be leaving the company on $18^{\text {th }}$ October 2011 (Hochtief AG, 2011c).

The second largest shareholder in Hochtief, Qatar Holding, announced on the $20^{\text {th }}$ April 2011 that it planned to increase its holding in Hochtief within the next twelve months ("Angestrebte Mehrheit: Katar will Anteil an Hochtief ausbauen," 2011).

ACS published its own list for the seats on the supervisory board on the $8^{\text {th }}$ May: Manfred Wennemer (already represented on the board), Abdulla Abdulaziz Turki Al-Subaie (representative of Qatar Holding LLC, Thomas Eichelmann (former CFO of Deutsche Börse AG; Eggert Voscherau (Chairman of the Supervisory Board of BASF SE), Marcelino Fernández Verdes (CEO of the Construction, Concessions and Environment and Logistics Areas of ACS - already represented on the board), Ángel García Altozano (Corporate General Manager, ACS - already represented on the board), Pedro Lopéz Jiménez (Member of the Board of Directors of ACS), José Luis del Valle Pérez (Member of the Board of Directors and Secretary General of ACS) (Actividades de Construccion y Servicios (ACS), 2011b). ACS has little or no influence upon the seats for the employee's representatives.

During the AGM on the $12^{\text {th }}$ May the list of Hochtief's current supervisory board was withdrawn and ACSs proposed list accepted (Hochtief AG, 2011d). ACS reported that they held 42.6\% of Hochtiefs shares (Finanznachrichten.de, 2011).

The Leighton Groups yearly results were published on $15^{\text {th }}$ May 2011 and were very disappointing. In the past Leighton had delivered good result, but in the past year they made a loss of 286 million $€$. This was reasoned by delays in two billion dollar projects (Australian). For Hochtief this resulted in a quarterly loss of 169.5 million $€$ compared to a profit in the previous year of 34.1 million $€($ "Australien-Tochter drückt Hochtief in die roten Zahlen," 2011).

On $17^{\text {th }}$ June 2011, ACS announced that it had acquired $50.16 \%$ of Hochtiefs shares and the next step is the integration of Hochtief ("Hochtief verliert Übernahmeschlacht: ACS kontrolliert Hochtief-Mehrheit," 2011). ACS had actually achieved its plan of obtaining control of Hochtief within one year and were able to consolidate its results in ACS.

As an epilogue it is interesting to note a few announcements which were made after ACS had acquired control of Hochtief. Leighton Holdings announced the sale of its iron ore contract mining division to BHP Billiton on $9^{\text {th }}$ August 2011. Leighton commented that the sale would free up 705 million $\$$ (Aus) for other investments and potentially higher returns, but it would forego approximately 1.1 billion $\$$ (Aus) per year in revenues (Wen, 2011). Hochtief announced on the $11^{\text {th }}$ September 2011 that the sale of its Airport division would be concluded in the near future. It was speculated that two companies remained in the negotiations, the French company Vinci and the Chinese company HNA, and that the price would be around 1.3 billion $€$ (Weishaupt, 2011b). On $31^{\text {st }}$ October 2011 Hochtief reported that three more top managers have taken advantage of their change of control clauses and would be leaving the company in the near future. All cited the reason for leaving as being "differences about the future strategy" of the company ("Nach ACS-Übernahme: Weitere Hochtief-Manager schmeißen hin," 2011).

\section{Conclusion}

This paper documents in detail the development of an international take-over process; consisting of both the offensive and defensive tactics used and when they were deployed in either a proactive or reactive manner.

It is evident that the focus of management interest extends from the typical financial perspective to the more complicated socio-political framework based upon each companies driving personalities, their controlling 
organizational bodies and relevant stakeholders. This implies that both companies should identify and manage their important stakeholders (groups) to maximise their effectiveness in acquisition or defence. This does not detract from the importance of adequate finance, but emphasises the importance to both the acquisition and target companies of understanding the socio-political framework within which the process takes place. Indeed, this becomes both more important and more difficult for international acquisitions where the acquirer and target companies belong to different socio-political groups.

A number of various tactics were used within the documented acquisition process; some of which could have perhaps been foreseen. As not all possible tactics are foreseeable, it is necessary that the management of the respective companies remain flexible to respond to any tactics used. This will normally mean that resources will have to be available and allocated at short notice.

For the acquiring company it implies that the socio-political framework of the target need to be understood before opening the bid and to prepare itself for any potential defence tactics. Indeed, it could be argued that this could be included in the decision to determine which target should be selected; as the consequences of an acquisition failure can be considerable.

For the target company, as it rarely knows whether it has become a target until it is too late to act, it should understand its own socio-political framework to determine its weaknesses and strengths and prepare its defence tactics accordingly. This could include using scenarios from fictive acquirers to develop and check its defence strategy.

\section{References}

ACS erhöht Anteil an Hochtief. (2008, February 25). Handelsblatt. Retrieved from http://www.handelsblatt.com/unternehmen/industrie/baukonzerne-acs-erhoeht-anteil-an-hochtief/2926304.html

ACS Group. (2007). ACS Group acquires 25,1\% of the German construction and concessions group Hochtief. Retrieved from http://www.grupoacs.com/adjuntos/2075_hochtief_gb_rev.pdf

ACS-Angriff auf Hochtief Ringfencing-Agreement soll Bonität sichern. (2010, December 29). Börse Online. Retrieved from http://www.boerse-online.de/aktie/nachrichten/deutschland/:ACS-Angriff-auf-Hochtief--Ringfencing-Agreeme nt-soll-Bonitaet-sichern/620130.html

Actividades de Construccion y Servicios (ACS). (2011a). Annual Report of ACS Group 2010. Retrieved from http://www.grupoacs.com/ficheros_editor/File/03_accionistas_inversores/03_informe_anual/2010/acs_group_a nnual_report.pdf

Actividades de Construccion y Servicios (ACS). (2011b). ACS publishes list of candidates for HOCHTIEF Supervisory Board elections. Retrieved from http://www.grupoacs.com/adjuntos/2734_acs_publica_lista_de_candidatos_9may11_eng.pdf

Actividades de Construccion y Servicios S.S. Stock Exchange Information. Retrieved from http://www.grupoacs.com/index.php/en/c/investorrelations

Angestrebte Mehrheit: Katar will Anteil an Hochtief ausbauen. (2011, April 21). Handelsblatt. Retrieved from http://www.handelsblatt.com/unternehmen/handel-dienstleister/angestrebte-mehrheit-katar-will-anteil-an-hochti ef-ausbauen/4090336.html

Aufgestockte ACS-Offerte nicht angemessen. (2010, December 17). Handelsblatt. Retrieved from http://www.handelsblatt.com/unternehmen/industrie/hochtief-aufgestockte-acs-offerte-nicht-angemessen/37405 54.html

Australien-Tochter drückt Hochtief in die roten Zahlen. (2011, May 16). Handelsblatt. Retrieved from http://www.handelsblatt.com/unternehmen/industrie/baukonzern-australien-tochter-drueckt-hochtief-in-die-rote n-zahlen/4178260.html

BaFin. (2011). No co-ordinated action between Southeastern and ACS established. Retrieved from http://www.bafin.de/SharedDocs/Veroeffentlichungen/EN/Pressemitteilung/2011/pm_110126_uebernahmeange bot_acs_hochtief_southeastern_angebotsaenderung_en.html

Baukonzern ACS kann Hochtief jetzt überrennen. (2010, November 19). Handelsblatt. Retrieved from http://www.handelsblatt.com/unternehmen/industrie/uebernahme-baukonzern-acs-kann-hochtief-jetzt-ueberrenn en/3643102.html 
Baukonzern Hochtief bleibt auf sich gestellt. (2010, October 19). NWZ online. Retrieved from

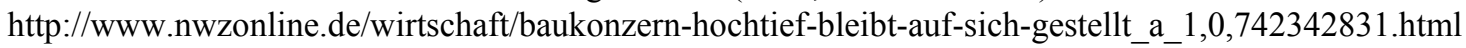

Baums, T. (2010). Low Balling, Creeping in und Deutsches Übernahmerecht.: Working Paper 122.

Construction M\&A activity rises globally in 2010. (2011, March 16). Construction Week Online. Retrieved from http://www.constructionweekonline.com/article-11419-construction-ma-activity-rises-globally-in-2010/

Datamonitor. (2010a). Company Profile ACS, Actiividas de Construccion y Servicios S.A. Business Source Premier (via EBSCO Host).

Datamonitor. (2010b). Company Profile Hochtief AG. Business Source Premier (via EBSCO Host).

Datamonitor. (2011). Global Homebuilding: Industry Profile. Retrieved from www.datamonitor.com

Deutsche Borse Group - Xetra. Chart - Börsenkurs. Retrieved from http://www.boerse-frankfurt.de/de/aktien/hochtief + ag+DE0006070006/charts

Engineering News record. (2011). The Top 225 International Contractors. Retrieved from http://www.stroytransgaz.ru/media/141292/2011-top_225_international_contractors.pdf

Fickling, D. (2010, November 8). Takeovers Panel rejects Leighton, Hochtief appeals. The Australian. Retrieved from

http://www.theaustralian.com.au/archive/business-old/takeovers-panel-rejects-leighton-hochtief-appeals/story-e 6frg96x-1225949273196

Finanznachrichten.de. (2011). ACS berichtet 42,6\% Anteil an Hochtief. Retrieved from www.finanznachrichten.de

Grüttner, A. (2011, January 5). Auf dem Sprung zur Weltspitze. Handelsblatt. Retrieved from http://www.handelsblatt.com/unternehmen/industrie/acs-chef-perez-auf-dem-sprung-zur-weltspitze/3755192.ht $\mathrm{ml}$

Hochtief AG. (2010a). Annual Report 2009. Retrieved from http://www.berichte.hochtief.de/qb10/download/137

Hochtief AG. (2010b). HOCHTIEF zum Übernahmeangebot von Actividades de Construcción y Servicios. Retrieved from http://www.hochtief.de/hochtief/pdfservice/8588

Hochtief AG. (2011a). Annual Report 2010. Retrieved from http://www.berichte.hochtief.de/download/142

Hochtief AG. (2011b). Dr. Herbert Lütkestratkötter scheidet zum 12. Mai 2011 aus dem Vorstand aus Vorstandsmitglied Dr. Frank Stieler wird Nachfolger. Retrieved from http://www.hochtief.de/hochtief/pdfservice/8778

Hochtief AG. (2011c). Veränderung im Vorstand der HOCHTIEF Aktiengesellschaft. Retrieved from http://www.hochtief.de/hochtief/pdfservice/8790

Hochtief AG. (2011d). Rücknahme der Kandidatur zur Aufsichtsratswahl bei HOCHTIEF. Retrieved from http://www.hochtief.de/hochtief/pdfservice/8806

Hochtief bietet ACS Gespräche an. (2010, December 12). manager magazin online. Retrieved from http://www.manager-magazin.de/unternehmen/artikel/0,2828,druck-734180,00.html

Hochtief kämpft weiter um australische Giftpille. (2010, October 20). Handelsblatt. Retrieved from http://www.handelsblatt.com/unternehmen/industrie/acs-uebernahme-hochtief-kaempft-weiter-um-australischegiftpille/3567978.html

Hochtief verliert Übernahmeschlacht: ACS kontrolliert Hochtief-Mehrheit. (2011, June 18). Finanzwirtschaftler. Retrieved

from http://www.finanzwirtschafter.de/18353-hochtief-verliert-uebernahmeschlacht-acs-kontrolliert-hochtief-mehrhe it/

Hochtief: Aufsichtsrat steht zur Abwehrfront. (2010, October 4). manager magazin online. Retrieved from http://www.manager-magazin.de/unternehmen/industrie/0,2828,druck-721129,00.html

Hochtief-Abwehr gegen ACS nimmt Formen an. (2010, October 25). Münsterland Zeitung. Retrieved from http://www.muensterlandzeitung.de/nachrichten/wirtschaft/ueberblick/Hochtief-Abwehr-gegen-ACS-nimmt-Fo rmen-an;art318,1074641\#

Hochtief-Aktionäre verschmähen ACS-Offerte: Feindliche Übernahme. (2010, December 9). Spiegel Online. Retrieved

from 
http://www.spiegel.de/wirtschaft/unternehmen/feindliche-uebernahme-hochtief-aktionaere-verschmaehen-acs-o fferte-a-733729-druck.html

Hochtief-Angreifer beschafft sich frisches Geld. (2010, November 26). Handelsblatt. Retrieved from http://www.handelsblatt.com/unternehmen/industrie/uebernahmekampf-hochtief-angreifer-beschafft-sich-frisch es-geld/3648622.html

Market Line. (2012). Global Construction \& Engineering: Market Line Industry Profile. Retrieved from www.marketline.com

Nach ACS-Übernahme: Weitere Hochtief-Manager schmeißen hin. (2011, October 31). Handelsblatt. Retrieved from

http://www.handelsblatt.com/unternehmen/industrie/nach-acs-uebernahme-weitere-hochtief-manager-schmeisse n-hin/5773896.html

Neuer Großaktionär aus Spanien. (2007, March 21). manager magazin online. Retrieved from http://www.manager-magazin.de/unternehmen/artikel/0,2828,druck-472887,00.html

Peter Noe geht: Erster Hochtief-Manager flieht vor ACS. (2011, March 11). Handelsblatt. Retrieved from http://www.handelsblatt.com/unternehmen/industrie/peter-noe-geht-erster-hochtief-manager-flieht-vor-acs/3941 456.html

Qatar Holding wird neue Großaktionär von Hochtief. (2010). Retrieved from http://www.hochtief.de/hochtief/pdfservice/8664

Reimann, E. (2010, January 21). Neuer Rückschlag für Hochtief im Übernahmekampf - Nachrichten Wirtschaft -. DIE WELT. Retrieved from http:/www.welt.de/wirtschaft/article12278799/Neuer-Rueckschlag-fuer-Hochtief-im-Uebernahmekampf.html

Schulz, S. (2011). Hochtief überrascht mit noch besserem Rekordergebnis. Retrieved from http://www.godmode-trader.de/nachricht/Hochtief-ueberrascht-mit-noch-besserem-Rekordergebnis,a2495826.ht $\mathrm{ml}$

SPIEGEL ONLINE. (2010). Hochtief-Betriebsrat fordert Rücktritt von Gewerkschaftern. Retrieved from $\mathrm{http}: / / w w w . s p i e g e l . d e / w i r t s c h a f t / u n t e r n e h m e n / n a c h-d e a l-m i t-a c s-h o c h t i e f-b e t r i e b s r a t-f o r d e r t-r u e c k t r i t t-v o n-g e$ werkschaftern-a-736947-druck.html

Statista Inc. Statista - Research Statistics. Retrieved from www.statista.com

Streit zwischen Hochtief-Aufsichtsrat und ACS eskaliert. (2011, March 31). Reuters. Retrieved from http://de.reuters.com/article/companiesNews/idDEBEE72U0CN20110331

Weishaupt, G. (2011a, January 4). Hochtief hofft auf BaFin als Retter in letzter Minute. Handelsblatt. Retrieved from http://www.handelsblatt.com/unternehmen/industrie/uebernahmekampf-mit-acs-hochtief-hofft-auf-bafin-als-rett er-in-letzter-minute/3754596.html

Weishaupt, G. (2011b, September 12). Hochtief steht kurz vor Flughafenverkauf. Handelsblatt. Retrieved from http://www.handelsblatt.com/unternehmen/handel-dienstleister/noch-zwei-bieter-hochtief-steht-kurz-vor-flugha fenverkauf/4600044.html

Wen, P. (2011, August 10). BHP to run own mines. The Sydney Morning Herald. Retrieved from http://www.smh.com.au/business/bhp-to-run-own-mines-20110809-1ikwp.html

Wenten, M. (2010, October 30). Hochtief-Mitarbeiter tragen Protest nach Berlin. Der Westen. Retrieved from http://www.derwesten.de/wirtschaft/hochtief-mitarbeiter-tragen-protest-nach-berlin-id3883141.html

Winand von Petersdorff. (2010, October 25). Lü der Baumeister. Frankfurter Allgemeine Zeitung. Retrieved from http://m.faz.net/aktuell/wirtschaft/unternehmen/hochtief-chef-luetkestratkoetter-lue-der-baumeister-1579519.ht $\mathrm{ml}$ 